\title{
GENETIC PROGRESS IN WINTER WHEAT CULTIVARS RELEASED IN CHILE FROM 1920 TO 2000
}

\author{
Iván Matus ${ }^{1}$, Mario Mellado ${ }^{1}$, Marcos Pinares ${ }^{1}$, Ricardo Madariaga $^{1}$, and Alejandro del Pozo ${ }^{2 *}$
}

\begin{abstract}
Wheat (Triticum aestivum L.) is the major crop in terms of planted area and presents the largest distribution in the country covering a wide range of climatic regions. This study assesses the changes of various agronomic traits of winter wheat cultivars released in Chile between 1920 and 2000. A total of 117 winter accessions, representing 45 old and 72 modern cultivars were tested in a humid Mediterranean-type climate, with irrigation, in 2003. Old cultivars were those released before 1960 and modern ones were those released after 1960. Principal component (PC) analysis using 10 agronomic traits clearly separate modern from old cultivars of winter wheat. Comparing modern cultivars with old ones, plant height have been reduced by $25.6 \%$, but others traits have increased, like harvest index (21.1\%), number of grains per ear (42.6\%), sedimentation value $(103 \%)$, and grain hardness $(32.0 \%)$. The variation in plant height was negatively correlated with harvest index $(r=-0.30, \mathrm{p}<0.001)$. Grain yield, a trait not included in PC analysis, was highly correlated with the second PC $(r=0.81, p<0.0001)$. Significant $(\mathrm{p}<0.01)$ correlations were found between the year of release of cultivars and agronomic traits: plant height $(\mathrm{r}=-0.82)$, harvest index $(\mathrm{r}=0.40)$, number of grain per ear $(\mathrm{r}=0.69)$, sedimentation value $(\mathrm{r}=0.64)$, and kernel weight $(\mathrm{r}=-0.46)$. Those correlations were mostly a consequence of absence or presence of dwarfing genes in the germplasm. Finally, the yield progress was calculated from yield data of yield trial with 15-25 cultivars and advanced lines of winter wheat tested almost every year from 1965 to 2001, showed no increase in yield between 1965 and 1975, but an increment of $246 \mathrm{~kg} \mathrm{ha}^{-1}$ per year between 1976 and 1998, representing an annual increase of $2.6 \%$.
\end{abstract}

Key words: Genetic improvement, grain quality, Mediterranean environment, old and new cultivars, principal components, yield progress.

$\mathrm{W}$ heat (Triticum aestivum L.) production is of great importance in Chile; is the major crop in terms of planted area and presents the largest distribution in the country covering a wide range of climatic regions, from the semi-arid Mediterranean-type climate $(\sim 350 \mathrm{~mm}$ of rain) of the northern zone to the humid temperate climate $(\sim 2000 \mathrm{~mm})$ of the southern zone. Winter wheat is mainly sown in southern part of the country where annual rainfall is $>1200 \mathrm{~mm}$.

From the early sixties, grain yield of wheat has increased significantly in both developed and developing countries (Calderini and Slafer, 1998), and worldwide (Miralles and Slafer, 2007). In Chile, before the sixties, the average yield was $1.3 \mathrm{Mg} \mathrm{ha}^{-1}$ and the cultivated area ranged between 600000 and 850000 ha; from the sixties to the present the average yield has increased significantly reaching $5.7 \mathrm{Mg} \mathrm{ha}^{-1}$ in the latest season, but the cultivated area has been reduced to 260000 ha (ODEPA, 2010).

${ }^{1}$ Instituto de Investigaciones Agropecuarias INIA, Casilla 426, Chillán, Chile.

${ }^{2}$ Universidad de Talca, Facultad de Ciencias Agrarias, Casilla 747, Talca, Chile. "Corresponding author (adelpozo@utalca.cl).

Received: 7 August 2011.

Accepted: 31 May 2012.
Plant breeding has had great impacts on productivity and grain quality of wheat in different countries (Zhou et al., 2007; Trethowan et al., 2007), including Chile (Mellado, 2007), leading to what has been called genetic progress (Foulkes et al., 2007). The introduction of semidwarfing genes in the sixties allowed the reduction in plant size, to increase harvest index, number of grains per unit area and grain yield (Flintham et al., 1997; Donmez et al., 2001; Brancourt-Hulmel et al., 2003; Zapata et al., 2004; Shearman et al., 2005), and to improve grain quality (Ortiz-Monasterio et al., 1997; Trethowan et al., 2007).

Over 200 cultivars have been released in Chile during the $20^{\text {th }}$ century (Mellado, 2007). The earlier cultivars (before 1950) were mostly introduced from Europe or USA, but afterward cultivars were created by breeding programs in Chile. In this paper we address the following questions: What have been the main changes in agronomic traits of winter wheat germplasm in Chile during the $20^{\text {th }}$ century? How grain quality has been modified by plant breeding? And to what extent genetic improvement and better agronomic practices are responsible of the strong increment in the average grain yield in Chile? Thus, the objectives of this study were: a) to analyze changes in various agronomic traits 
of winter cultivars released or introduced in the country between 1920 and 2000 ; b) to identify what traits have contribute most to the genetic improvement of winter wheat cultivars in Chile; and c) to analyze the yield progress in winter bread wheat.

\section{MATERIALS AND METHODS}

\section{Characterization of winter germplasm}

A total of 117 winter wheat accessions, representing 45 old and 72 modern cultivars were tested in field experiments in 2003. Seeds were obtained from the Germplasm Bank of CRI-Quilamapu of Instituto de Investigaciones Agropecuarias INIA. Cultivars were released or introduced in the country between 1920 and 2000; old cultivars are those used before 1960 while modern ones are those released after 1960. The experiment was conducted in the experimental field of CRI-Quilamapu, located $25 \mathrm{~km}$ from Chillán (36³2' S; 71 ${ }^{\circ} 54^{\prime} \mathrm{W}$; $217 \mathrm{~m}$ a.s.1.), Chile. The climate corresponds to a humid Mediterranean type; the long term average of the minimum temperature of the coldest month (July) is $3.0^{\circ} \mathrm{C}$; the maximum temperature of warmest month (January) is $28.6{ }^{\circ} \mathrm{C}$; the annual temperature is 13.9 ${ }^{\circ} \mathrm{C}$; and the annual rainfall is $1270 \mathrm{~mm}$ (del Pozo and del Canto, 1999). The soil was a sandy loam, humic Haploxerands (Andisol). Soil chemical characteristics of the top $10 \mathrm{~cm}$ were: $\mathrm{pH} 6.0,8.87 \mathrm{mg} \mathrm{N}-\mathrm{NO}_{3} \mathrm{~kg}^{-1} ; 17.05$ mg $\mathrm{P} \mathrm{kg}^{-1}$ (Olsen), $0.45 \% \mathrm{~N}$-total, $4.5 \% \mathrm{C}$ and $0.33,5.75$, $0.65,0.48, \mathrm{cmol} \mathrm{kg}^{-1}$ of available $\mathrm{K}, \mathrm{Ca}, \mathrm{Mg}$ and $\mathrm{Na}$, respectively (Zagal et al., 2002).

Plots consisted of two rows of $2 \mathrm{~m}$ long separated by $0.2 \mathrm{~m}$ and the seeding rate was $180 \mathrm{~kg} \mathrm{ha}^{-1}$, with no replicates. Sowing date was 2 June. Fertilizer application was done on 1 ha basis of $180 \mathrm{~kg} \mathrm{~N}, 52 \mathrm{~kg} \mathrm{P}, 66 \mathrm{~kg} \mathrm{~K}$, $23 \mathrm{~kg} \mathrm{Mg}, 44 \mathrm{~kg} \mathrm{~S}, 1,1 \mathrm{~kg} \mathrm{~B}$ and $1.05 \mathrm{~kg} \mathrm{Zn.} \mathrm{Nitrogen}$ was split into three, $47 \mathrm{~kg}$ at planting (Zadoks 00), $80 \mathrm{~kg}$ at tillering initiation (Zadoks 20) and $53 \mathrm{~kg}$ at the end of tillering (Zadoks 25). Weeds were controlled with MCPA at $750 \mathrm{~g}$ a.i. ha-1 + metsulfuron methyl $8 \mathrm{~g}$ a.i. ha-1. Plots were furrow irrigated according the necessity of the crop.

Ten traits were evaluated: plant height $(\mathrm{cm})$, days to heading, grain yield, harvest index, ear length (average of 20 ears), test weight $\left(\mathrm{kg} \mathrm{hL}^{-1}\right)$, number of grain per ear (average of 20 ear), 1000 kernel weight (g), wet gluten content (\%) (Promylograph type TIK, Austria), sedimentation value $\left(\mathrm{cm}^{3}\right)$ (Zeleny, 1947), and grain hardness index. The latter determined as the grain resistance to abrasion in a pearler machine (Strong Scott 17810, Seedburo Equipment, Chicago, Illinois, USA), and therefore low values in hardness index (\%) means harder grains.

Graphical representation of the estimated genetic similarities between genotypes was obtained by principal component (PC) analysis using the above quantitative traits, excluded grain yield. Only those components with an eigenvalue greater than 1.0 were selected. Correlation values between the original characters and their respective principal components were obtained by multiplying the square root of the eigenvalue for each component by the eigenvector of each character evaluated. Only correlation values $\geq 0.65$ were considered as relevant for that principal component.

The PC analysis was done by the procedure PROC PRINCOMP using SAS V 8e (SAS Institute, 2001). One-way ANOVAs were performed to compare traits of old and modern cultivars. Correlation analyses were performed between grain yield and the scores of PCs, and between scores of PCs and the year of cultivar release. Finally, correlations were performed between traits and year of cultivar release.

\section{Yield progress analysis}

Grain yield data of 15-25 cultivars and advanced lines of winter wheat tested almost every year from 1965 to 2001 , by the wheat breeding program of CRI-Quilamapu, INIA, was used to analyze the yield progress. All the evaluations were conducted at the experimental field of CRI-Quilamapu under irrigated conditions. Plots consisted of six rows of $2 \mathrm{~m}$ long separated by $0.2 \mathrm{~m}$ with four replicates. Sowing dates were May-June. All plots were fertilized according to soil analysis and weeds controlled with herbicides and/ or manually. To estimate grain yield, an area of $2 \mathrm{~m}^{2}$ was harvested at maturity.

\section{RESULTS}

\section{Agronomic traits and year of cultivar release}

The first three PCs explained $72.4 \%$ of the total variance (Table 1). The first component explained $43.2 \%$ of the total variance and in general separated modern from old cultivars (Figure 1); the former were located on the left side of PC 1 and were characterized by lower plant height, greater number of grains per ear and better grain quality, i.e., higher values of wet gluten and sedimentation value,

Table 1. Eigenvectors and cumulative variance of the most important principal components (PC) for 10 quantitative traits of winter (45 old and 72 modern) cultivars of wheat, evaluated at the experimental field of CRIQuilamapu in 2003. In bold are the relevant traits for each PC.

\begin{tabular}{lccr}
\hline & \multicolumn{3}{c}{ Principal components } \\
\cline { 2 - 4 } Traits & PCI & PC2 & PC3 \\
\hline Plant height, cm & $\mathbf{0 . 8 4}$ & -0.08 & 0.24 \\
Days to heading & 0.26 & -0.62 & -0.34 \\
Ear length, cm & $\mathbf{- 0 . 6 6}$ & 0.14 & -0.09 \\
Harvest index & -0.18 & $\mathbf{0 . 8 4}$ & -0.28 \\
Test weight, kg hL ${ }^{-1}$ & 0.61 & 0.55 & 0.41 \\
Number of grains per ear & $\mathbf{- 0 . 6 6}$ & 0.44 & -0.42 \\
1000 kernel weight, g & 0.68 & 0.49 & 0.13 \\
Wet gluten content, \% & $\mathbf{- 0 . 7 9}$ & -0.18 & 0.38 \\
Sedimentation value, $\mathrm{cm}^{3}$ & $\mathbf{- 0 . 7 7}$ & 0.05 & 0.45 \\
Hardness index & $\mathbf{0 . 7 6}$ & -0.01 & -0.24 \\
\hline \% variance explained & 43.3 & 18.8 & 10.3 \\
Cumulative variance & 43.3 & 62.1 & 72.4 \\
\hline
\end{tabular}




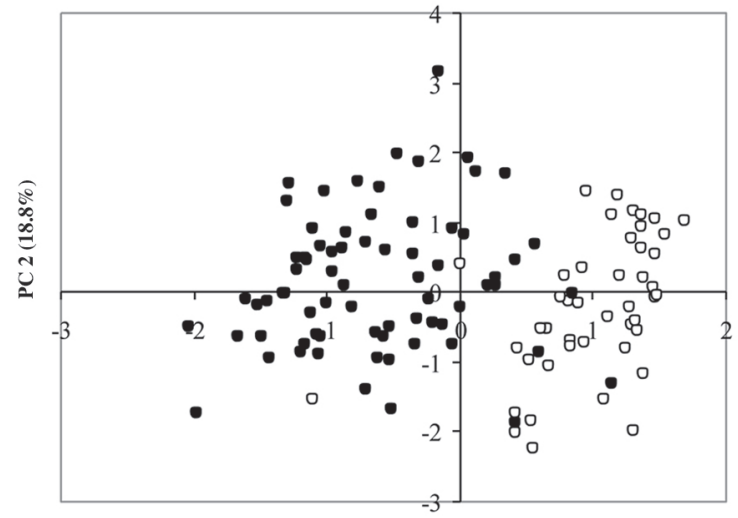

PC $1(43.3 \%)$

Figure 1. Scatter diagram of the first two principal components $(\mathrm{PC})$ for 45 old $(O)$ and 72 modern $(\bullet)$ winter wheat cultivars evaluated at the experimental field of CRI-Quilamapu in 2003. PC 1 and PC 2 explained 43.3 and $18.8 \%$ of the variance, respectively.

and lower hardness index (harder grains) (Table 1). The second PC explained $18.8 \%$ of the total variance and was positively correlated with harvest index (Table 1). Significant differences (ANOVAs; $\mathrm{p}<0.001$ ) between old (released before 1960) and modern (released after 1960) cultivars of winter wheat were found for all evaluated traits (Table 2). In modern cultivars plant height and 1000 kernel weight were reduced by 25.6 and $20.9 \%$, respectively, whereas harvest index, ear length, number of grains per ear were increased by $21,18.8$ and $42.6 \%$, respectively. Regarding grain quality, wet gluten content and sedimentation value were augmented by 54.4 and $103 \%$, respectively; however test weight and hardness index were reduced by 20.9 and 32\%, respectively. Days to heading was slightly reduced in modern cultivars (Table 2). Grain yield, a trait not included in PC analysis, was highly correlated with PC 2 (Table 3 ). The year of release was negatively correlated with PC 1 , indicating that those agronomic traits related with $\mathrm{PCs}$ are contributing to the yield improvement of wheat. In fact, the year of release was positively correlated with harvest index, ear length and number of grain per ear (Table 4). Traits related with grain quality were also positively correlated with the year of release, like wet gluten and sedimentation value (Table 4). However, as expected, plant height was negatively

Table 2. Mean (standard error) values of traits of old and modern winter cultivars evaluated at the experimental field of CRI-Quilamapu in 2003.

\begin{tabular}{lccrc}
\hline Trait & Old $(\mathrm{N}=45)$ & Modern $(\mathrm{N}=72)$ & \multicolumn{1}{c}{$\mathrm{F}$} & $\mathrm{P}$ \\
\hline Plant height, m & $136.1(1.8)$ & $101.3(1.5)$ & 179.9 & 0.000 \\
Days to heading & $163.0(0.9)$ & $159.3(0.7)$ & 9.3 & 0.003 \\
Harvest index & $0.19(0.01)$ & $0.23(0.01)$ & 14.6 & 0.000 \\
Ear length, cm & $8.5(0.2)$ & $10.1(0.2)$ & 33.2 & 0.000 \\
Number of grains per ear & $28.9(1.1)$ & $41.2(0.9)$ & 73.7 & 0.000 \\
1000 kernel weight, g & $39.3(1.1)$ & $31.1(0.9)$ & 32.4 & 0.000 \\
Test weight, kg hL I $^{-1}$ & $76.1(0.6)$ & $72.3(0.5)$ & 23.9 & 0.000 \\
Wet gluten content, \% & $17.1(1.0)$ & $26.4(0.8)$ & 49.5 & 0.000 \\
Sedimentation value, $\mathrm{cm}^{3}$ & $8.8(1.0)$ & $17.9(0.8)$ & 45.9 & 0.000 \\
Hardness index & $41.9(1.3)$ & $28.5(1.0)$ & 68.4 & 0.000 \\
\hline
\end{tabular}

Table 3. Pearson correlation values for the relationship between the year of release of cultivars and grain yield with the scores of principal components (PC).

\begin{tabular}{lcc}
\hline Principal component & Year of release & Grain yield \\
\hline PC 1 & $-0.85^{* *}$ & -0.01 \\
PC 2 & 0.24 & $0.81^{* *}$ \\
PC 3 & -0.09 & -0.14 \\
\hline
\end{tabular}

${ }^{* *}$ Correlations are significant at the 0.005 level.

Table 4. Correlations between year of release and traits of winter wheat cultivars evaluated at the experimental field of CRI-Quilamapu in 2003.

\begin{tabular}{lc}
\hline & Winter $(\mathrm{N}=117)$ \\
\hline Plant height, cm & $-0.82^{*}$ \\
Days to heading & $-0.29^{*}$ \\
Harvest index & $0.40^{*}$ \\
Ear length, cm & $0.53^{*}$ \\
Number of grains per ear & $0.69^{*}$ \\
1000 kernel weight, g & $-0.46^{*}$ \\
Test weight, kg hL ${ }^{-1}$ & $-0.39^{*}$ \\
Wet gluten content, $\%$ & $0.60^{*}$ \\
Sedimentation value, $\mathrm{cm}^{3}$ & $0.63^{*}$ \\
Hardness index & $-0.66^{*}$ \\
Grain yield, Mg ha &
\end{tabular}

${ }^{*}$ Correlations are significant at the 0.01 level.

correlated with year of release and so do 1000 kernel weight, test weight and hardness index (Table 4). The number of grain per ear was positively $(r=0.49 ; \mathrm{p}<0.01)$ with ear length, but negatively correlated $(r=-0.28 ; \mathrm{p}<$ 0.01) with 1000 kernel weight.

\section{Yield progress}

Frequency distribution of grain yield indicate higher grain yield in modern cultivars than in older ones (Figure 2). As a consequence, grain yield was positively correlated with year of release (Table 4). Using a more extensive set of data available from INIA trials, average yield values of commercial cultivars and experimental lines of winter wheat evaluated from 1965 to 2001, show a null yield progress from 1965 to 1975 (average yield 4.2 $\mathrm{Mg} \mathrm{ha}^{-1}$ ), then an increase in yield from 1976 to the middle nineties, with 2 yr (1996 and 1998) with average yields higher than $10 \mathrm{Mg} \mathrm{ha}^{-1}$ (Figure 3).

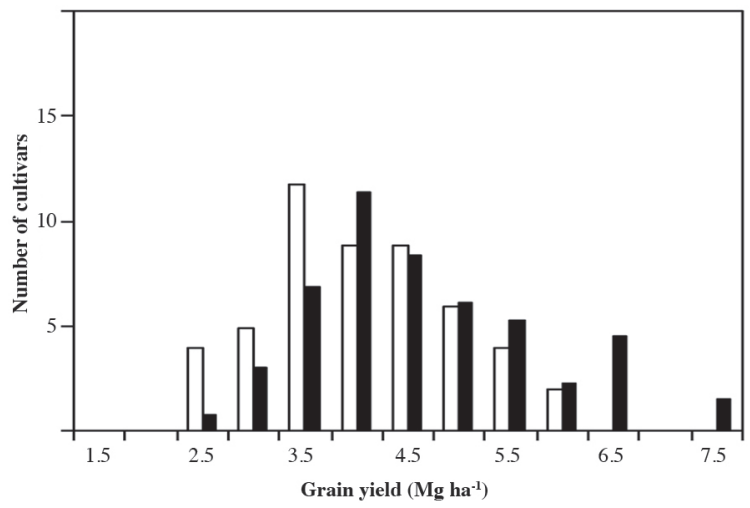

Figure 2. Frequency distribution of grain yield of old $(O)$ and modern (•) winter wheat cultivars evaluated at the experimental field of CRIQuilamapu in 2003. 


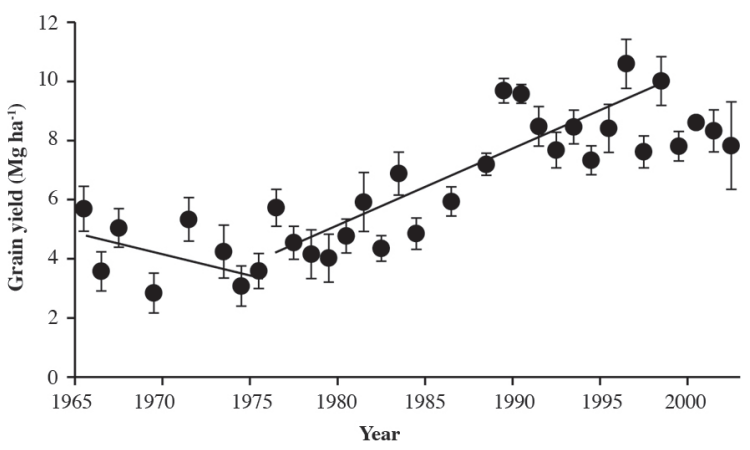

Figure 3. Yield progress in winter wheat. Values are the mean of 15-25 cultivars tested each year at the experimental field of CRI-Quilamapu between 1965 and 2001. The lineal regression between 1976 and 1998 is: $y$ $=0.2461 x-482.11 ; R^{2}=0.70$.

\section{DISCUSSION}

Comparing modern cultivars with old ones (released before the sixties) a number of traits have changed in winter cultivars (Table 2); plant height have been reduced by $25.6 \%$, but others traits have increased, like harvest index $(21.1 \%)$ and number of grain per ear $(42.6 \%)$. Similar changes in these agronomic traits have been observed with genetic improvement in UK (Flintham et al., 1997; Shearman et al., 2005), France (Brancourt-Hulmel et al., 2003), North America (Donmez et al., 2001), Italia (Guarda et al., 2004) and Argentina (Slafer and Andrade, 1989). The variation in plant height was negatively correlated with harvest index $(\mathrm{r}=-0.30, \mathrm{p}<0.001)$, as has been reported by other authors (Richards, 1992; Evans, 1993; Mellado, 2000).

The reduction of plant height is a consequence of the introduction of semi-dwarfing genes which were introduced in Chile in 1956 (Zapata et al., 2004). As a consequence, the significant correlations between year of release and plant height, harvest index or number of kernel per ear, observed in winter cultivars (Table 4), as well as in other studies (e.g. Shearman et al., 2005; Zhou et al., 2007), is mostly due to the absence or presence of dwarfing genes in the germplasm. In fact, the correlations are not significant when the analysis is performed for year of release from 1970 onwards, i.e. for wheat germplasm with dwarfing genes. The increase in number of grains per ear is a consequence of Rht pleiotropy (Flintham et al., 1997), which in the case of the Chilean germplasm the dwarfing genes derive mainly from the cultivar Norin 10 (Mellado, 2007).

In Chile crosses of spring by winter types have been performed, and the selection has been driven to facultative type. As a consequence a slight reduction in days to heading has been obtained in modern winter cultivars (Table 2). Kernel weight has been reduced in modern cultivars (Tables 2 and 4), and this can be explained because kernel weight has not been a selection target by breeders in Chile, and also due to the strong increase in the number of grains per ear. In Italy, kernel weight of winter wheat also decreased between 1900 and 1994 (Guarda et al., 2004). In North China, kernel weight of bread wheat was not modified between the sixties and the year 2000 (Zhou et al., 2007). But, in durum wheat growing in a Mediterranean environment in Turkey, kernel weight was superior in modern cultivars (Koç et al., 2003).

The yield progress has been extensively analyzed by different authors, either as trends of national averages (e.g. Calderini and Slafer, 1998) or as progress of yield potential (e.g. Sayre et al., 1997; Fischer, 2007; Foulkes et al., 2007). The later has been estimated comparing the yield of cultivars from different year of release; in Centro Internacional de Mejoramiento de Maíz y Trigo (CIMMYT), Mexico, under irrigated conditions, the genetic progress for spring bread wheat was $0.41 \%$ per year between 1966 and 2003 (Fischer, 2007), and 0.88\% per year comparing eight cultivars released between 1962 and 1988 (Sayre et al., 1997). For durum wheat, the rate of progress has been estimated in $0.49 \%$ per year between 1966 and 2003 (Fischer, 2007). In North China, the annual genetic progress ranged 0.48-1.05\% (32.0-72.1 $\left.\mathrm{kg} \mathrm{ha}^{-1}\right)$, in three Provinces, for cultivars released between the sixties and the nineties (Zhou et al., 2007). In this study, the yield progress, calculated from yield data of winter cultivars tested from 1965 to 2001, is $246 \mathrm{~kg} \mathrm{ha}^{-1} \mathrm{yr}^{-1}$ (2.6\%) between 1976 and 1998, but in this evaluation there are confounded both genetic and agronomic improvements. For the same period (1976-1998) the average grain yield in Chile increased at the rate of $118 \mathrm{~kg} \mathrm{ha}^{-1} \mathrm{yr}^{-1}$ (from 1.5 to $3.2 \mathrm{Mg} \mathrm{ha}^{-1}$; ODEPA, 2010), that is an increase of $3.7 \%$ per year. Therefore, the yield gap (calculated as the yield obtained in experimental trials - average country yield) increased from $2.7 \mathrm{Mg} \mathrm{ha}^{-1}$ in 1976 to $6.4 \mathrm{Mg} \mathrm{ha}^{-1}$ in 1998 .

Other important traits modified by plant breeding are those related to grain quality; the sedimentation value and wet gluten have increased in modern cultivars (103\% and $54.4 \%$, respectively; Table 2) and were positively correlated with year of release (Table 4). In a previous study, where cultivars of spring (10 cultivars) and winter (11 cultivars) wheat released between 1968 and 1993 were compared, the sedimentation value showed no progress during that period, but it did grain protein content which increased 0.5-1.0\% (Mellado, 2001). The analysis of 37 cultivars released between 1955 and 2005 in the former Yugoslavia, revealed that plant breeding increased grain protein content (close related to sedimentation value), but reduced wet gluten (Dencic et al., 2005).

\section{CONCLUSIONS}

Changes in a number of traits have occurred in winter wheat cultivars in Chile as a consequence of plant breeding; plant height and kernel weight has been reduced but harvest index and number of grain per ear have increased. Also, grain quality traits have been modified; higher sedimentation values and lower hardness index (harder grains) are observed in modern's wheat. The yield 
progress in Chile between 1976 and 1998 has been very high which explains the strong increment in the average grain yield of the country, in the last decades.

\section{ACKNOWLEDGEMENTS}

We thank Prof. Peter Caligari for critical review of the manuscript.

\section{Progreso genético en cultivares de trigo de invierno} liberados en Chile desde 1920 a 2000. El trigo (Triticum aestivum L.) es el cultivo más importante en Chile en términos de superficie sembrada y áreas geográficas en las cuales se siembra, cubriendo una gran diversidad de condiciones climáticas. Este estudio evaluó los cambios de varias características agronómicas de variedades de trigo de invierno liberadas en el país entre 1920 y 2000. Un total de 117 genotipos de trigos de invierno, que representa 45 cultivares antiguos y 72 cultivares modernos, se evaluaron en un clima húmedo de tipo mediterráneo, en condiciones de riego, en el año 2003. Los cultivares antiguos corresponden a aquellos liberados antes del año 1960 y los modernos a los liberados después del año 1960. Mediante un análisis de componentes principales (CP) usando 10 características agronómicas, permitió separar claramente los cultivares modernos de los antiguos. Al comparar los cultivares modernos con los antiguos se determinó que la altura de la planta se ha reducido un $25,6 \%$, pero en otras características se produjo un aumento, como el índice de cosecha $(21,1 \%)$, número de granos por espiga (42,6\%), valor de sedimentación (103\%) y la dureza del grano $(32,0 \%)$. La variación en la altura de la planta se correlacionó negativamente con el índice de cosecha $(r=-0,30, p<0,001)$. El rendimiento de grano, una característica no incluida en el análisis de PC, estuvo altamente correlacionado con el segundo PC $(r=0,81$, $\mathrm{p}<0,0001)$. Correlaciones significativas $(\mathrm{p}<0,01)$ se encontraron entre el año de la liberación de los cultivares y las características agronómicas: altura de planta $(\mathrm{r}=$ $-0,82)$, índice de cosecha $(r=0,40)$, número de granos por espiga $(0,69)$, valor de sedimentación $(r=0,64)$, y peso del grano $(r=-0,46)$. Estas correlaciones fueron en su mayoría una consecuencia de ausencia o presencia de genes de enanismo en el germoplasma. Finalmente el avance en rendimiento, calculado a partir de datos de rendimiento de ensayos en los que se probaron entre 15 y 25 cultivares y líneas avanzadas de trigo de invierno evaluados casi todos los años entre 1965 y hasta 2001, no mostró ningún aumento en el rendimiento entre 1965 y 1975, pero sí un aumento de $246 \mathrm{~kg} \mathrm{ha}^{-1}$ por año entre 1976 y 1998 , lo que representa un incremento anual de $2,6 \%$.

Palabras clave: mejoramiento genético, calidad del grano, clima mediterráneo, cultivares antiguos y mejorados, componentes principales, avance genético del rendimiento.

\section{LITERATURE CITED}

Brancourt-Hulmel, M., G. Doussinault, C. Lecomte, P. Bérard, B. Le Buanec, and M. Trottet. 2003. Genetic improvement of agronomic traits of winter wheat cultivars released in France from 1946 to 1992. Crop Science 43:37-45.

Calderini, D.F., and G.A. Slafer. 1998. Changes in yield and yield stability in wheat during the 20th Century. Field Crops Research 57:335-347.

Del Pozo, A., y P. del Canto. 1999. Áreas agroclimáticas y sistemas productivos en las VII y VIII Regiones. Ministerio de Agricultura Instituto de Investigaciones Agropecuarias INIA, Centro Regional de Investigación Quilamapu, Chillán, Chile.

Dencic, S., B. Kobiljski, N. Mladenov, N. Hristov, and M. Pavlovic. 2005. Long-term breeding for bread making quality in wheat. p. 495-501. In HT Buck, J.E., Nisi, and N. Salomón (eds.) Wheat production in stressed environments. Springer, Dordrecht, The Netherlands.

Donmez, E., R.G. Sears, J.P. Shroyer, and G.M. Paulsen. 2001. Genetic gain in yield attributes of winter wheat in the Great Plains. Crop Science 41:1412-1419.

Evans, L.T. 1993. Crop evolution, adaptation and yield. Cambridge University Press, Cambridge, UK.

Fischer, R.A. 2007. Understanding the physiological basis of yield potential in wheat. Journal of Agriculture Science 145:99-113.

Flintham, J.E., A. Börner, A.J. Worland, and M.D. Gale. 1997. Optimising wheat grain yield effects of Rht (gibberellin insensitive) dwarfing genes. Journal of Agriculture Science 128:11-25

Foulkes, M.J., J.W. Snape, V.J. Shearman, M.P. Reynolds, O. Gaju, and R. Sylvester-Bradley. 2007. Genetic progress in yield potential in wheat: recent advances and future prospects. Journal of Agriculture Science 145:17-29.

Guarda, G., S. Padovan, and G. Delogu. 2004. Grain yield, nitrogenuse efficiency and baking quality of old and modern Italian breadwheat cultivars grown at different nitrogen levels. European Journal of Agronomy 21:181-192.

Koç, M., B. Celaleddin, and I. Genç. 2003. Photosynthesis and productivity of old and modern durum wheats in a Mediterranean environment. Crop Science 43:2089-2098.

Mellado, M. 2000. Mejoramiento de trigos harineros (Triticum aestivum L.) en la zona centro-sur de Chile. II. Análisis del rendimiento y variables asociadas en trigos de primavera. Agricultura Técnica 60:32-42.

Mellado, M. 2001. Mejoramiento de trigos harineros (Triticum aestivum L.) en la zona centro sur de chile. III. Contenido y producción de proteína, y volumen de sedimentación en trigos invernales, alternativos y primaverales. Agricultura Técnica 61:120-128.

Mellado, M. 2007. El trigo en Chile. 684 p. Colección Libros INIA $\mathrm{N}^{\circ} 21$. Instituto de Investigaciones Agropecuarias, Centro Regional de Investigación Quilamapu, Chillán, Chile.

Miralles, D.J., and G.A. Slafer. 2007. Sink limitations to yield in wheat: how could it be reduced? Journal of Agricultural Science 145:139-149.

ODEPA. 2010. Estadísticas y precios. Cultivos anuales: superficie, producción y rendimientos. Oficina de Estudios y Políticas Agrarias (ODEPA), Santiago, Chile. Available at http://www. odepa.cl/articulos/MostrarDetalle.action;jsessionid=7344AA34B 4BC9AE8CFAF9091491B7030?idcla=12\&idn=1736 (accessed 12 May 2011)

Ortiz-Monasterio, J.I., R.J. Peñna, K.D. Sayre, and S. Rajaram. 1997. CIMMYT's genetic progress in wheat grain quality under four nitrogen rates. Crop Science 37:892-898.

Richards, R.A. 1992. The effect of dwarfing genes in spring wheat in dry environments. I. Agronomic characteristics. Australian Journal of Agriculture Research 43:517-527.

SAS Institute. 2001. SAS OnlineDoc®, Version 8. SAS Institute Inc., Cary, North Carolina, USA. 
Sayre, K.D., S. Rajaram, and R.A. Fischer. 1997. Yield progress in short bread wheats in northwest Mexico. Crop Science 37:36-42.

Shearman V.J., R. Sylvester-Bradley, R.K. Scott, and M.J. Foulkes. 2005. Physiological processes associated with wheat yield progress in the UK. Crop Science 45:175-185.

Slafer, G.A., and F.H. Andrade. 1989. Genetic improvement in bread wheat (Triticum aestivum L.) yield in Argentina. Field Crops Research 21:289-296.

Trethowan, R.M., M.P. Reynolds, J.I. Ortiz-Monasterio, and R. Ortiz. 2007. The genetic basis of the green revolution in wheat production. Plant Breeding Reviews 28:39-58.

Zagal, E., N. Rodríguez, I. Vidal, and L. Quezada. 2002. Actividad microbiana en un suelo de origen volcánico bajo distinto manejo agronómico. Agricultura Técnica 62:297-309.
Zapata, C., P. Silva, and E. Acevedo. 2004. Comportamiento de isolíneas de altura en relación con el rendimiento y distribución de asimilados en trigo. Agricultura Técnica 64:139-155.

Zeleny, L. 1947. A simple sedimentation test for estimating the bread-baking and gluten qualities of wheat flour. Cereal Chemistry 24:465-475.

Zhou, Y., Z.H. He, X.M. Chen, D.S. Wang, J. Yan, X.C. Xia, and Y. Zhang. 2007. Genetic improvement of wheat yield potential in North China. p. 583-589. In Buck, H.T., J.E. Nisi, and N. Salomon (eds.) Wheat production in stressed environments. Springer, Dordrecht, The Netherlands. 